\title{
EUPHEMISMS THROUGH TIME: THE RHETORICAL POWER OF PALLIATION*
}

\author{
UDC 81'373.49
}

\author{
Milica Radulović \\ University of Niš, Faculty of Philosophy, English Department, Serbia
}

\begin{abstract}
The paper is an overview of the ideas and theoretical frameworks relevant to studying euphemisms, words/expressions used for the purpose of avoiding the negative effect associated with non-euphemistic more negatively connoted alternatives. Euphemisms are discussed in relation to rhetoric, stylistics, pragmatics and discourse analysis, which all provide insight into the motives for the use of these palliative expressions. The overview of the ideas shows that different theoretical frameworks, though they belong to different periods of time, recognize euphemisms as a convenient tool for communicating meaning in a way that can support only the speaker's interests. This means that euphemisms can be discussed as a type of language use by means of which the speaker can impose a preferred interpretation of meaning, and, as far as the motives for euphemization are concerned, they should be examined more closely in accordance with the specificities of context and discourse in which euphemisms are used.
\end{abstract}

Key Words: euphemism, rhetoric, stylistics, pragmatics, discursive strategies

\section{INTRODUCTION}

The term 'euphemism' comes from Greek euphēmismos, derived from euphēmizein, which means "to use terms of good omen, to speak favourably" (Partridge 1966: 1002-1003). Many authors have defined, classified, and analyzed euphemisms and euphemization, and they include both the ancient authors and those from modern times (to name some of them, Allan and Burridge 2006, Alm-Arvius 2003, Aristotel 2000, Burkhardt 2010, Burridge 2005, Dešić 1990, Gorčević 2011, Habinek 2005, Kovačević 2000, 2006, Kuna 2007, Lanham 1991, Luchtenberg 1985, Lutz 1989, Mišić Ilić and Radulović 2014, Mišković-Luković 1993, Moritz 2015, Penelope 1981, Quintilianus 2001, Radulović 2012, Ristić 2004, Strozier 1966, Sytnyk 2014, Šebková 2012, Warren 1992). This paper is an overview of the ideas and theoretical frameworks relevant to studying euphemisms and their functional role of

Submitted May $15^{\text {th }} 2016$, accepted for publication November $6^{\text {th }}, 2016$

Corresponding author: Milica Radulović

Faculty of Philosophy, University of Niš, Serbia

E-mail: mlcradulovic2@gmail.com

* The paper is based on part of the author's $\mathrm{PhD}$ thesis Euphemisms in English and Serbian Public Discourse. 
palliating/reducing the negative expressive force of the utterance/sentence in which they are used. Euphemisms are probably most frequently discussed as rhetorical/stylistic devices (Section 2), but they can be analyzed from the point of view of pragmatics and discourse analysis, which also study ways in which language use can affect the auditor/audience (Sections 3 and 4). The overview shows that euphemisms can be defined as a type of language use by means of which the speaker can impose a preferred interpretation of meaning, and it also shows that the speaker's motives for euphemization are closely related to specific contextual and discursive aspects of language use. In Section 4, three possible motives for euphemization are discussed: face-preserving motives, concealment and irony.

\section{RHETORIC, STYLISTICS AND RHETORICALITY}

\subsection{Rhetoric and stylistics}

Rhetoric, broadly defined as "the art of persuasion" (Lanham 1991: 131), from the Greek rhetorike techne - "art of an orator", was originally seen as the craft of speechmaking, a study of the methods of persuasion by orators. Rhetoric teaches us that one of the most important communicative functions of language is the function of persuasion. The five phases of rhetoric summarized by Quintilian (Lanham 1991: 165), invention, arrangement, expression/ style, memory and delivery/action, indicate that preparing a speech is a structured process; the speech itself is a construct, not a random use of words and sentences without premeditation. The classification of the stages of rhetoric also discovers the roots of stylistics, today a sub-discipline of linguistics. In this sense, the phase of elocution, expression or style, has a very important role, as it refers to the use of specific language devices suited to achieve specific oratorical goals.

The notion of style was well-known even before Quintilian; in his treatise on rhetoric, Aristotle (Serbian translation, Aristotel 2000: 191) talks about three points to study in making a speech: sources from which methods of persuasion are drawn, the style of expression, and the arrangement of the parts of the speech. He points out that it is not only important to know what should be said, but it is also important to produce the right impression in speech. Similarly to Aristotle, according to the traditional division of labour within rhetoric, stylistics is concerned with the way arguments are presented, suggesting that arguments can be expressed in different manners, and should be related to invention and arrangement in such a way as to achieve the right effect on the audience.

\subsection{Euphemisms and other rhetorical/stylistic devices}

In the most general sense, euphemisms are rhetorical/stylistic devices employed by the speaker to reduce the negative expressive potential of the sentence/utterance, motivated by a conviction that a more direct expression can be disturbing or damaging for the speaker and the hearer. In that sense, euphemisms prognosticate good things, they are the "opposite of Ominatio (Lanham 1991: 72)".

Aristotle (Aristotel 2000: III, 2, 199-200) saw euphemisms as a subtype of metaphor, and Quintilian (2001: VIII, 6, 57) mentioned them as special forms of allegory. Broadly speaking, they can be regarded as rhetorical/stylistic figures, and figures can be defined as "any striking or unusual configuration of words or phrases (Lanham 1991: 78)". Figures 
can be divided into two subgroups, figures of words and figures of thought; metaphor is a figure of words, and allegory is a figure of thought (Lanham 1991: 178). ${ }^{1}$

In his famous treatise on rhetoric, Aristotle (2000: 199-200) refers to metaphors as devices that give clearness, charm and distinction to style. For example, pirates can call themselves purveyors, a crime can be called a mistake, a mistake a crime, a thief can take a thing (even nowadays the verb take can be a euphemism for the verb steal). Here it is obvious that Aristotle was well-aware of the possibility of adjusting speech in accordance with the effect we want to achieve, and the given examples suggest that euphemisms can rely on metaphorical meaning extension. ${ }^{2}$

Quintilian had a similar idea about the nature of euphemisms; he saw them as a form of allegory. In his Handlist of Rhetorical Terms, Lanham (1991: 4) defines allegory as a metaphor extended through an entire speech. Aristotle's and Quintilian's views of euphemisms show that making clear-cut divisions between figures is not that easy (euphemisms can be seen both as metaphors and allegories). Classical rhetoricians were all aware of these fuzzy boundaries, so these overlapping cases are found in many classical manuals. Also, as they are all revisions of classical taxonomies, modern rhetorical/stylistic handbooks do not offer sharply divided classifications either. For example, according to Lanham's (1991: 181-196) own alphabetical list of rhetorical terms, euphemisms belong to two types of rhetorical devices. Specifically, they belong to the group of terms used to achieve a specific type of emotional appeal, achieved either by means of prognostication of something good, or by means of circumlocution to palliate something unpleasant (Lanham 1991: 187). This definition stresses the perlocutionary function of euphemisms. Also, euphemisms belong to what Lanham (1991: 189) categorizes as metaphorical substitutions and puns. Alm-Arvius (2003: 148-149) also classifies euphemisms as a type of puns whose function is to achieve a humorous effect. In another classification put forward by Habinek (2005: 105-107), metaphors are listed as tropes, but euphemisms are not mentioned explicitly. In his classification, litotes, another type of deliberate understatement is given (for example, "She is dishonest" becomes the litotes "She is not honest"). Litotes are close in communicative function to euphemisms, as both euphemisms and litotes achieve the effect of understating meaning.

In addition to litotes, other rhetorical/stylistic devices can be used to achieve similar palliative effects. Cicero used the term verecundia (reservedness, discretion) and verba tecta (covered words), and Bede (1975: 163) called euphemisms Charientismos (good behaviour, decency) (Burkhardt 2010: 355-356). Cicero's term verecundia, or politeness of respect, refers to the use of language appropriate in a particular social context. The term verecundia can be related to the logical fallacy ad verecundiam discussed by Locke (1690/1999: 682), the appeal to authority or expertise (Tindale 2007: 127), or awedirected argument (Van Eemeren, Garssen and Meuffels 2009:7). Verecundia means 'shame', 'shyness', 'modesty', and the argument ad verecundiam is an argument based

\footnotetext{
${ }^{1}$ Burke (2014: 1-2) discusses two types of stylisation, the one based on the clarity, preciseness and appropriateness of language, and the one based on style figures. These are schemes, which deviate at the syntactic level of language, and tropes, which deviate at the semantic level. Similarly to this, Burkhardt (2010: 358) talks about two subtypes of euphemisms, syntactic (sentential level) and lexical (subsentential level).

2 The view that "metaphor is a conceptual rather than a purely linguistic phenomenon (Evans and Green 2006: 43-44)" was brought into focus by Lakoff and Johnson (1980, 1999), and, today, it is widely discussed in cognitive linguistics. Metaphorization relies on the possibility of meaning extension, where a conceptual domain is formed by means of another one.
} 
on respect for authority (Hamblin 1970: 42-43). In other words, this means that we may believe something not because we have reasons to do so, but because we rely on someone's authority, be it knowledge, status, political power.

Cicero used the words verecundia and verba tecta, which emphasize the social function of euphemisms, but he also discussed figures that are used for the purpose of euphemizing. In the classification of figures given in Rhetorica Ad Herennium (Cicero was thought to have written this Latin book of rhetoric), which was highly influential in the Middle Ages and the Renaissance, stylistic devices closely associated with euphemisms are discussed. For example, metaphor and allegory are seen as tropes which, among other things, can be used for the purpose of minifying ([Cicero] 1954/ 1964: 343-345). Another trope in this classification that can be brought into relation with euphemisms is periphrasis, a device used to express an idea by means of circumlocution. If words are replaced with euphemistic periphrases for the purpose of being vague, then the connection between euphemisms and periphrasis is obvious.

In the English Renaissance, euphemism was used in the sense of "prognostication of good" (Burkhardt 2010: 355-356). This is a definition that does not say much about euphemisms, apart from stating its general communicative function. However, the Renaissance period was much more fruitful regarding the questions of rhetoric and especially style than this definition would suggest. It is the period of rediscovering the ancient authorities on rhetoric, and questioning the relation between philosophy and rhetoric. Rhetoric was seen as a method of achieving both personal and political power; rhetoric led to personal refinement, provided instructions how to think deeply, and helped in winning political battles through arguments (Herrick 2005: 153). Owing to Gutenberg's printing press, such rhetorical education was available to a larger number of people. Indeed, the Renaissance was the period of publishing an enormous number of books on rhetoric and style manuals.

In his book On Copia of Words and Ideas (1512/1999), Erasmus discusses the issue of the importance of expressing thoughts using the right words. Erasmus lists different ways of varying speech (such as, for example, synonymy, periphrasis, metaphor, allegory). He mentions diminution (Erasmus 1512/1999: 35); for example, instead of saying "one has struck another", we can say "one has touched him". Euphemisms can also be related to periphrasis, or circuitio, a method of varying speech where many words are used instead of a single word (Erasmus 1512/1999: 27).

Rhetoric even makes it possible to present vices as virtues. For example, Peacham (1593/1996: 163) defines paradiastole, a term of speech that can be related to euphemisms; this is the use of language where the truth is opposed by false terms and names, for example, in using good fellowship instead of drunkeness. Puttenham (1589/ 1968: 154) defines paradiastole as an ornament employed to make the best of a bad thing, to moderate and abate the force by craft. Skinner (2007: 149-163) talks about paradiastole as a rhetorical redescribing of vices as virtues. Skinner (2007: 157) even suggests that classical writers on the ars rhetorica took pride in the ability of powerful orators to make us change our minds about the way we see certain things. He gives the example of Cicero's De Oratore, in which Crassus expresses the view that this might be the greatest rhetorical skill, the skill to argue in utramque partem, on either side of the case. This type of rhetorical expertise is close to doubletalk, or "dishonest euphemism", where circumlocution is practised consciously (Rawson 1981: 3). 
One of the most famous style manuals from the Renaissance period is Henry Peacham's handbook The Garden of Eloquence (1593/1996), where a long list of stylistic terms is given, including tropes of words, tropes of sentences, figures of repetition, omission, conjunction, separation, figures of sentences, exclamation, moderation, consultation, permission. According to Peacham (1593/1996: 87-92), euphemisms belong to figures of moderation. He explains that this figure is used to give consolation, hope and encouragement. However, besides the ideal use of figures, Peacham was aware of the possibility of manipulation. Therefore, after defining and explaining the use of each figure, he discusses how figures can be abused. Euphemisms, for instance, can turn into deceitful flattery or malicious fraud.

This review points out that it is not always easy to draw clear dividing lines between euphemisms and other stylistic figures or tropes. The analysis, therefore, suggests that identifying euphemisms means identifying words/expressions that have the potential to reduce negative connotations of words/expressions in specific contexts/discourses.

\subsection{Rhetoricality}

Classical rhetoric had to be abandoned because, as Bender and Wellbury (1990: 25) argue, it "rarified speech and fixed it within a gridwork of limitations." The principles of rhetoric, the authors further explain, were conditioned by the institutions that led interaction in traditional European society. On the other hand, rhetoricality is not limited by any set of institutions; rhetoricality is not a set of strategies used in the language of persuasion, it becomes "something like the condition of our existence (Bender and Wellbury 1990: 25)".This conception of language reconciles with the idea that meaning in language is not a stable sign-signifier relationship. Language is understood as profoundly and persuasively figurative; tropes and figures cannot be rationalized and their use cannot be controlled. Such a view of rhetoric where language in its totality is viewed as rhetorical is known as rhetoricality (Bender and Wellbery 1990: 25).

In order to give more insight into the transition from rhetoric to rhetoricality, Bender and Wellbery (1990: 23-24) explain that rhetoricality was grounded in several cultural presuppositions. First of all, modernism is characterized by the loss of faith in the neutrality of scientific and practical discourse. Bender and Wellbery (1990: 23) explain that in modernism, even so-called observation sentences are recognized as theory-laden, and the history of science is a series of constructions governed by specific conceptual paradigms. Likewise, Perelman and Olbrechts-Tyteca (1969: 133) explain that outside of pure formalism, notions can be clear and univocal only in relation to a field of application that is known and determined. The necessity of using univocal language, which dominates the scientific thought, loses sight of the fact that this clarity may stand in the way of other functions of language. If language is then used for purposes other than those science is interested in (such as, for example, the purpose of persuasion and manipulation), it is not surprising that univocality gives way to ambiguity and plurality of meaning. This condition of language can be dangerous, because ambiguity of meaning can lead to moral ambiguity.

The second presupposition refers to dismantling the values of individual authorship and creativity. Classical rhetoric saw language as a tool for structuring argumentation according to what the orator intends to achieve. However, modernism abandons the idea that we are fully creative or free in creating meaning in accordance with our intentions. Derrida (2002: 111), the French philosopher whose ideas had a strong influence on 
rhetorical thinking, holds that our being is an inheritance, and that the language we speak is an inheritance. He emphasizes that it is not the inheritance that we possess, but the inheritance that we are. Because we think only in signs, and when we think about meaning, we think about signs (Derrida 1976: 50) which are inherited, it is impossible for us to be completely free creators of meaning. Traditional notions like "structure", "opposition", and "meaning" force stability on concepts that are fundamentally unstable, and obfuscate the operations by means of which the appearance of stability is created (Herrick 2005: 256). This is so because a signifier carries with itself the possibility of its own repetition, of its own image or resemblance. When the sign appears, it is not possible to encounter anywhere the purity of "reality," "unicity," "singularity" (Derrida 1976: 91). Herrick (2005: 257), for example, illustrates Derrida's idea with the instability of the meaning of the term war. Although we can say that this is a stable term, it is only defined in contrast to its opposite, peace. If we argue about a possibility of war, at the same time, we argue about the opposite concept, peace.

Thirdly, modernism developed together with the mass consumption of ideas where rhetorical manipulation is a rule. Marketing, propaganda and public relations create public opinion. Perelman and Olbrechts-Tyteca (1969: 4) name the 20th century the century of advertising and propaganda, and argumentation depends on the audience we address.

The fourth presupposition discussed by Bender and Wellbery (1990: 24) is the dethroning of print. The authors think that in modernism, film and television dominate mass communications. This change is a change in the nature of communication; mass media enter our lives, and these types of public discourse become important areas of research.

Lastly, in modernism, the idea of national uniqueness and national language is abandoned. Dialects, sociolects and idiolects multiply; new disciplines and their new jargons are created. Finally, all these conditions make it necessary to analyze euphemisms and euphemization in relation to specific types of discourses, not as isolated context and discourse-free rhetorical devices.

\section{Pragmatic Perspectives}

\subsection{Introduction}

Pragmatics studies the principles of communication underlying the communicative interaction between the speaker (here the euphemizer) and the hearer; it pays close attention not only to the speaker's but to the hearer's role in communication as well. Pragmatics can also give insight into the speaker's motives for the use of euphemisms and indicate how the hearer can recognize euphemisms. To explain, we introduce Grice's Cooperative Principle (1975, 1989), the face-saving principles of communication discussed within the more socially oriented framework of politeness theory (Brown and Levinson 1978/1987), Habermas's socially oriented theory of communicative action (1998), and, finally, the cognitively oriented relevance-theoretic approach to communication (abbreviated as RT) (Sperber and Wilson 1995).

\subsection{Grice: Cooperative Principle}

Communication is cooperation where participants are expected to follow "a rough general principle", the Cooperative Principle (Grice 1989: 26-27): 
Make your conversational contribution such as is required, at the stage at which it occurs, by the accepted purpose or direction of the talk exchange in which you are engaged.

This principle is further elaborated into four maxims: the maxim of Quantity, the maxim of Quality, the maxim of Relation and the maxim of Manner. Grice (1975: 48) suggests that it is reasonable to follow the standard type of conversational practice, although it does not necessarily mean that we sometimes do not abandon such reasoning. The two rational interlocutors first compute literal meaning, and then, if it is recognized that a maxim is violated, the intended meaning is derived my means of implicatures. However, as we may not always be able to recognize the violation of the Cooperative Principle, or the speaker and the hearer may well differ/disagree in their judgements of the violation of the Cooperative Principle, we come to two basic types of communication: on the one hand, communication can be cooperation, and, on the other hand, it can be recognizable and nonrecognizable (for the hearer) violations of the Cooperative Principle. If it is the nonrecognizable violation of the Cooperative Principle, it can be strategic verbal manipulation. Euphemisms, in this sense, can be regarded as either recognizable or non-recognizable violation of the Cooperative Principle. This can be related to Luchtenberg's (1985: 24) basic distinction of euphemisms between the ones whose function is veiling, and the ones whose function is concealing: veiling euphemisms can be viewed as recognizable euphemisms, and concealing euphemisms can be viewed as non-recognizable euphemisms.

\subsection{Politeness theory: face-preserving principles of communication}

Most generally speaking, Brown and Levinson's study of politeness deals with the facepreserving principles of communication. Brown and Levinson (1978/1987: 95) suggest that the reason it is impossible to observe Grice's maxims (as universal principles of cooperative communication) to the letter is that the speaker and the hearer are motivated by the desire to satisfy face wants. Grice (1989: 28) himself was aware that, in addition to CP, there could be other types of maxims, such as, for example, "Be polite" maxim, which may influence the generation of non-conventional implicatures (cf. Cicero's view of euphemisms as verecundia and verba tecta, using the appropriate language in a specific social context, Section 2.2.).

According to Brown and Levinson (1978/1987: 68-71), when a face- threatening act (FTA) is performed (a speaker may choose not to do the FTA if it is possible), it can be classified as an "on-record" or an "off-record" face-threatening act. The "on-record" FTA is the act whose communicative intention is clear and unambiguous. As far as "offrecord" face-threatening acts are concerned, Brown and Levinson (1978/1987: 213-214) talk about fifteen strategies (ways to reach certain goals in communication) the speaker can use to lead the hearer to a specific inference. They are based on violating Gricean maxims of communication:

Violate Relevance Maxim: 1) give hints, 2) give association clues, 3) presuppose;

Violate Quantity Maxim: 4) understate, 5) overstate, 6) use tautologies;

Violate Quality Maxim: 7) use contradictions, 8) be ironic, 9) use metaphors, 10) use rhetorical questions;

Violate Manner Maxim: 11) be ambiguous, 12) be vague, 13) over-generalize, 14) displace $H, 15$ ) be incomplete, use ellipsis.

The authors (1978/1987: 216, 226) suggest that euphemisms for taboo topics can be violations of the Maxim of Relevance, Strategy 2: give association clues. They, do, 
however, remark that some euphemisms are of the associative kind, and some are metaphorical, and metaphors themselves are listed as the violation of the Quality maxim, Strategy 9 (use metaphors), and they can be violations of the Maxim of Manner (Strategy 12 , be vague).

\subsection{Habermas's communicative action}

Abstracting universal principles of communication is the starting point for analyzing the process of reaching understanding, and also, it is the starting point for the analysis of the processes of misunderstanding, lack of understanding, untruthfulness, discord (open and concealed), and all cases when the presupposed principles of communication are breached (Habermas 1998: 25). Habermas (1998: 93) puts forward a classification of different types of social action (speech acts are a specific type of social action):

Social Action:

a) Communicative action

Action-oriented toward reaching understanding

Consensual action (action and discourse)

b) Strategic action

Openly strategic action

Latently strategic action

(manipulation and systematically distorted communication)

Euphemisms can be products of either consensual or strategic actions. As already mentioned, Luchtenberg (1985: 24) classifies euphemisms into those whose aim is to veil and those whose aim is to conceal meaning. Following this classification, veiling euphemisms can be regarded as a result of consensual action, and concealing euphemisms can be regarded as a type of latent strategic action.

\subsection{Relevance-theoretic principles of communication}

Sperber and Wilson's (1995) relevance theory explains the relation between communication and cognition. Sperber and Wilson (1995: 260-261) argue that:

Human cognition tends to be geared to the maximisation of relevance;

Every act of ostensive communication communicates a presumption of its optimal relevance.

In his considerations of the relation between relevance theory and the making and understanding of rhetorical arguments, Campbell (1992) suggests that relevance theory can explain how the rationalistic version of the communication of rhetorical arguments can be undermined, bearing in mind that RT sees rational relevances as only one type of relevances, in addition to strategic ones. Seen in this way, we avoid the "rationalistic bias", as communication is not only about implying and inferring that utterances can prove certain claims, but it also includes people's awareness of how arguments can achieve ends. Unlike theories with the "rationalistic bias" whose aim is to study discourse free from strategic and ideological aspects, and whose rationality means understanding reasons as reasons (Campbell 1992: 146), relevance theory takes into account that language is a means of achieving goals in communication, and therefore this "rationalistic 
bias" is avoided. In this way, relevance theory is close to rhetoric and rhetoricality discussed in Section 2, which stress the probabilistic nature of discourse.

Relevance theory underscores the crucial role of context in making sense of what the speaker produces. Sperber and Wilson (1995: 15-16) define context as a set of premises we use in the interpretation of an utterance. The central question related to context selection is how we create an appropriate context out of the repository of diverse information and experiences. As the authors (1995: 16) explain, if we belong to the same linguistic community, we rely on the same language in addition to relying on the same inferential abilities, but we do not rely on the same assumptions about the world: grammar is a force which neutralizes differences in storing experiences but cognition works in the opposite direction, it stores inevitable differences in our experiences. This, however, gives the speaker an opportunity to control and manipulate context selection, which is exactly what s/he can do when euphemisms are used. The less accessible contextual assumptions are, the more effort is needed to retrieve the information the speaker would prefer to hide.

In line with this, Sytnyk's (2014) central claim is that "the cognitive processing of utterances containing novel euphemistic/politically correct locutions involves metarepresentations of saliently unexpressed dispreferred alternatives". As further argued, the hearer is invited to infer the dispreferred non-euphemistic equivalents in the process of explicature derivation. However, in certain discourses, the speaker may choose not to "invite" the hearer to infer the dispreferred non-euphemistic equivalents. Concealing euphemisms, for example, can be used as strategies by means of which the hearer is distracted from inferring the relation between the euphemism and the non-euphemistic more negatively connoted alternative.

\section{EUPHEMIZATION AS A DISCURSIVE STRATEGY}

\subsection{Introduction}

In their discourse analysis of discriminatory practices, Reisigl and Wodak (2001: 44) ${ }^{3}$ define discursive strategies as systematic ways of using language, or "a more or less accurate and more or less intentional plan of practices (including discursive practices) adopted to achieve a particular social, political, psychological or linguistic aim". There is a difference between argumentation ready for rational negotiation and argumentation as its strategical perversion, i.e. manipulation (Reisigl and Wodak 2001: 70). Chilton (2011: 180-181) argues that linguistic structures are not inherently manipulative; what makes them

\footnotetext{
${ }^{3}$ Reisigl and Wodak's (2001: 44-45) classification includes five types of discursive strategies. The first type includes intensifying/mitigation strategies which help modify the epistemic status of a proposition by intensifying or reducing the illocutionary force of utterances. The second type contains referential strategies (nomination strategies), which are used to construct and represent social actors. The third type includes predicational strategies (strategies for assigning qualities), which include attributions of negative and positive traits in the linguistic form of implicit or explicit predicates, aimed at labeling social actors more or less positively or negatively. The fourth type comprises argumentation strategies and a set of topoi which justify positive and negative attributions. Topoi, or loci, are parts of argumentation belonging to explicit or inferable premises (Reisigl and Wodak 2001: 74-75), such as topos of responsibility, topos of authority, topos of justice, topos of power. Finally, Reisigl and Wodak's (2001: 44-45) classification ends with perspectivation, framing or discourse representation, which is the way speakers express their involvement in discourse and position their view in the reporting, description, narration or quotation.
} 
manipulative are humans who act on their goal-directed intentions. According to the author, making the hearer form a thought or a belief about certain aspects of reality is an example of such manipulative intentions, and discursive strategies (as verbal action) can achieve the goal of changing the hearer's representation of social and physical reality. One such strategy is euphemization, the strategy of palliating/reducing the negative expressive force of the utterance, differently motivated in different discourses. In the next section, three possible motives for euphemization are discussed: face-preserving euphemization/politeness (avoiding offensive explicitness, verecundia), concealment (dissimulation, duplicity, distancing) and irony (criticism, distancing, expressing negative attitudes).

\subsection{Politeness strategies}

Veiling euphemisms are face-preserving euphemisms. They are words/expressions belonging to religious and social taboos, i.e. language expressions through which invocation of danger, embarrassment or social disgrace are avoided. These expressions are used as alternatives for the language considered to possess magical powers (the power of evil, disease, death), and for the language that breaks the norms of common decency, and is basic to creating a positive public image (such as, for example, euphemisms that replace explicit mention of words/expressions related to sexuality, disease, bodily fluids).

Rawson (1981: 1-3) discusses another type of face-preserving euphemisms, those that are motivated by the speaker's wish to make euphemized referents look more important than they are. These are occupational titles, personal honorifics, institutional euphemisms. For example, the positive euphemism custodian replaces janitor, help replaces servant, parlors, salons replace small businesses (see Rawson 1981: 1-2).

Finally, concealing euphemisms are instances of "off-record" FTAs, or indirect, equivocal communication. The speaker who uses concealing euphemisms can be accused of manipulating politeness strategies, but the payoff is that the speaker can avoid the responsibility for face-damaging interpretations as "every blatant indirectness may be defensible as innocent (Brown and Levinson 1978/1987: 212)". In addition to avoiding responsibility for doing an FTA, the speaker leaves it up to the hearer to interpret the act as a threatening or a non-threatening one (Brown and Levinson 1978/1987: 211).

\subsection{Concealment}

By using concealing euphemisms, speakers can distance themselves from negatively connoted non-euphemistic terms and transfer the responsibility to the hearer to infer implied meaning. For example, in the political speech made by Ed Miliband, the positively connoted euphemistic verb stabilize can be brought into relation with the negatively connoted antonym destabilise:

[...] For that reason, right now this country has troops engaged in Afghanistan.

They represent the very best of our country.

They and their families are making enormous sacrifices on our behalf and we should today acknowledge their service and their sacrifice.

Our troops are there to stabilise the country and enable a political settlement to be reached so that Afghanistan can be stable and we can be safe.

I will work in a bi-partisan way with the government to both support our mission and ensure Afghanistan is not a war without end. 
But just as I support the mission in Afghanistan as a necessary response to terrorism, I've got to be honest with you about the lessons of Iraq [...]

(Miliband: Leader's speech, Manchester 28 September 2010)

Both stabilize and destabilise have the relevant diagnostic feature [become different], but, the former implies [become stable], and the latter implies [become unstable]. When something is qualified as unstable, questions related to the diagnostic feature [stable] (and [unstable]) can be asked: stable for whom? stable in what sense? The answer to the first question is: the speaker prefers to foreground the diagnostic feature [stable], so any further specification of meaning depends on the co-text and context/background information and assumptions related to the topic discussed. Here, the co-text and context make it clear that stabilisation is related to the topic of conflicts/war, so the opposite diagnostic feature [become unstable], which is related to the antonym war, becomes relevant in this context as well.

The language of warfare used for the purpose of concealment and deception has its name - militarese (Allan and Burridge 2006: 230-231). Some additional examples are: pacify instead of "be killing", neutralize for "kill selected targets", recovered components for "the remains of those killed" (Allan and Burridge 2006: 228-236).

As the information given in public cannot be the information that discredits the speaker/politician, negative public response specific words/expressions can produce in political discourse can be avoided by means of euphemization. In that way, the politician can not only symbolically distance him/herself from non-euphemistic, more negatively connoted terms (as s/he does not use/utter them), but s/he can also symbolically distance $\mathrm{him} /$ herself from the actors and actions denoted by non-euphemistic terms.

\subsection{Irony}

Euphemization can be a strategy for expressing irony. In the following extract taken from a newspaper article that deals with a case of corruption, the use of the word gift can be interpreted as a euphemism used in place of the much more negatively connoted word bribe:

[...] Mr. McDonnell can dodge accountability, but his damage-control campaign speaks louder than his words. On Tuesday he announced that he would return a number of gifts which, though he failed to specify them, presumably will cover goodies that he and his wife received from businessman Jonnie R. Williams Sr. Those include a \$6,500 Rolex; $\$ 15,000$ to cover part of a catering bill for the wedding of his daughter; and another $\$ 15,000$ run up by Mrs. McDonnell, on Mr Williams's tab, at Bergdorf Goodman, the New York luxury department store. $[\ldots]$

The governor said he did not know about 'some of the gifts' at the time they were given. (Not, presumably, the Rolex on his wrist.) He said he would return whatever 'I have received.' 'Does that mean he will see to it that his wife also returns the $\$ 15,000$ in merchandise from Bergdorf? [...]

(Editorial Board: The Evasive Mr. McDonnell, The Washington Post, 31 July 2013)

Traditionally, an ironical utterance is analyzed as literally saying one thing and figuratively meaning the opposite (Sperber and Wilson 1981: 295, Wilson and Sperber 1992: 53). However, the above-mentioned example is not that free from ambiguity. First of all, indirect reported speech (The governor said...) informs us about the content of an 
attributed thought, i.e. the author of the article attributes a thought to the governor. Also, separating some of the gifts and I have received with inverted commas indicates that the author of the article distances himself/herself from these words. The author's distance/dissociative attitude can be interpreted as the author's rejection of the given words and the author's negative ironical attitude towards the governor's attitude to the word gift, which is actually a replacement for a non-euphemistic negatively connoted word bribe.

Wilson and Sperber (2012: 4-5) argue that irony can also be viewed as "echoing a thought (e.g. a belief, an intention, a norm-based expectation), attributed to an individual, a group, or to people in general, and expressing a mocking, skeptical or critical attitude to this thought". Therefore, irony can imply that the speaker believes the opposite of what was said, but this is not the meaning and neither is it the point of the utterance (Wilson and Sperber 2012: 5). Irony is used as a strategy for criticizing since norms, as Wilson and Sperber (2012: 35) suggest, are always prone to being ironically echoed when they are not respected. As the analyzed example comes from a newspaper article, this means that the authors of newspaper articles can use euphemisms to critically evaluate actions performed by social actors, and, by doing that, they can also expose euphemization as a verbal strategy used for concealment and rhetorical palliation.

\section{CONCLUSION}

The paper shows that euphemisms have been studied extensively, and that a variety of theoretical frameworks can contribute to giving insight into how and why euphemisms are used. First of all, euphemisms are discussed in relation to rhetoric and stylistics, which, above all, highlight the communicative function of persuasion. Rhetoricality, the new modernist paradigm, sheds more light on how language in general, and euphemisms in particular, are used. Language is not a system of representation whose signs have a fixed value, and, therefore, it is important to study the relation between euphemisms and a particular type of discourse where they are used, larger structural units that control the production and interpretation of meaning. This connection can be related to the shift from the centrality of spoken discourse and the dominant role of orators/rhetoricians, to the insistence on the introduction of written discourse, which, in addition to public speechmaking, becomes another important way to address and influence public opinion (e.g. newspaper discourse). Another shift is crucial in the study of language use, the shift from the focus on the speaker to the focus on the communicative interaction between the speaker and the hearer, and the focus on the question why certain words/expressions are used. The paper shows that, in order to establish specific motives for euphemization, contexts (co-textual aspects, the topic discussed and the information/assumptions related to specific topics) and the type of discourse need to be taken into account. Some of these specific motives have been singled out and analyzed at the end of the paper: the most benevolent face-preserving considerations (for example, positive euphemisms), concealment (militarese), and irony/criticism. 


\section{REFERENCES}

Allan, K. and K. Burridge., (2006), Forbidden Words: Taboo and the Censoring of Language, Cambridge University Press, Cambridge.

Alm-Arvius, C., (2003), Figures of Speech, Studentlitteratur, Lund.

Aristotel, (2000),Retorika, prevod sa starohelenskog i komentari dr Višić, M., ur. Marić,I., Plato, Beograd.

Bede V., (1975), "De Schematibus et tropis II: De tropis", Corpus Christianorum. Series Latina 123A, 1: pp.151-171.

Bender, J.,and D. E. Wellbery, (1990),"Rhetoricality: On the Modernist Return of Rhetoric”. In: Bender, J. and Wellbery, D. E. (eds.), The Ends of Rhetoric: History, Theory, Practice, Stanford University Press, Stanford, California: pp. 3-39.

Brown, P. and S. Levinson, (1978/1987), Politeness. Some Universals in Language Use, Cambridge University Press, Cambridge.

Burke, M., (2014). "Stylistics: From Classical Rhetoric to Cognitive Neuroscience", In: Burke, M. (ed.) The Routledge Handbook of Stylistics, Routledge, London and New York: pp. 1-7.

Burkhardt, A., (2010), “Euphemism and Truth”,. In: Burkhardt, A. and Nerlich, B. (eds.), Tropical Truth(s): The Epistemology of Metaphors and Other Tropes, Walter de Gruyter GmbH \& Co. KG Berlin/ New York: pp.355-372.

Burridge, K., (2005), Weeds in the Garden of Words: Further Observations on the Tangled History of the English Language, Cambridge University Press, Cambridge.

Campbell, J. L., (1992), "An Applied Relevance Theory of the Making and Understanding of Rhetorical Arguments" Language \& Communication 12, № 2: pp. 145-155.

Chilton, P., (2011), "Manipulation", In: Zienkowski, J., ÖstmanJ-O.,and Verschueren, J. (eds.) Discursive Pragmatics, John Benjamins Publishing,Amsterdam/Philadelphia:pp. 176-189.

Chilton, P. and C. Schäffner, (2002), "Introduction: Themes and Principles in the Analysis of Political Discourse”, In: Chilton, P. and Schäffner, C. (eds.) Politics as Text and Talk: Analytic Approaches to Political Discourse, John Benjamins Publishing Company, Amsterdam/Philadelphia: pp. 1-41.

[Cicero, M. T.] (1954/1964), Ad C. Herennium de Ratione Dicendi (Rhetorica Ad Herennium). translated by Caplan, H., edited by Page,T. E. et al. William Heinemann Ltd, London; Harvard University Press, Cambridge, Massachusetts.

Derrida, J., (1976), Of Grammatology, Corrected edition,translated by Spivak, G. C., The Johns Hopkins University Press, Baltimore and London.

Derrida, J., (2002), Negotiations: Interventions and Interviews, 1971-2001,edited, translated and with an Introduction by E. Rottenberg, Stanford University Press, Stanford, California.

Dešić, M., (1990), Iz srpskohrvatske leksike, NIO „Univerzitetska riječ”, Nikšić.

Erasmus, D., (1512/ 1999), On Copia of Words and Ideas. De Utraque Verborum ac Rerum Copia Mediaeval, translated from the Latin with an introduction by King, D. B., and Rix,H. D., Marquette University Press, Milwaukee, Wisconsin.

Evans, V. and M. Green, (2006), Cognitive Linguistics. An Introduction, Edinburgh University Press, Edinburgh.

Gorčević, A., (2011), Eufemizmi i disfemizmi u engleskom jeziku, Doktorska disertacija. Filološki fakultet u Beogradu.

Grice, P., (1975), "Logic and Conversation", In: Cole, P. and Morgan, J. L. (eds.), Syntax and Semantics Volume 3: Speech Acts, Academic Press, New York: pp.41-58.

Grice, P., (1989), Studies in the Way of Words, Harvard University Press Cambridge, Massachusetts; London, England.

Habermas, J., (1998), On the Pragmatics of Communication, The MIT Press, Cambridge, Massachusetts.

Habinek, T., (2005), Ancient Rhetoric and Oratory, Blackwell Publishing, Malden MA.

Hamblin, C.L., (1970), Fallacies, Methuen \& Co Ltd, London.

Herrick, J. A., (2005), The History and Theory of Rhetoric: An Introduction, $3^{\text {rd }}$ edition, Pearson Education, Boston.

Jorgensen, M. and L.J. Phillips, (2002), Discourse Analysis as Theory and Method. Sage Publications, London/ Thousand Oaks/New Delhi.

Kovačević, M., (2000), Stilistika i gramatika stilskih figura, Kantakuzin, Kragujevac.

Kovačević, M., (2006), "O tipovima i stilskim osobinama disfemizama i eufemizama", U: Jovanović, V. i Stojanović, M. (ur.), Godišnjak za srpski jezik i književnost, godina XX, broj 8, Filozofski fakultet, Niš: str. 193-227.

Kuna, B., (2007), "Identifikacija eufemizama i njihova tvorba u hrvatskom jeziku”, Fluminensia, god. 19; br. 1, str. 95113 .

Lakoff, G. and M. Johnson, (1980), Metaphors We Live by, University of Chicago Press, Chicago.

Lakoff, G. and M. Johnson, (1999), Philosophy in the Flesh: The Embodied Mind and its Challenge to Western Thought, Basic Books, New York. 
Lanham, R. A., (1991), A Handlist of Rhetorical Terms, $2^{\text {nd }}$ edition, University of California Press, Berkley/Los Angeles/London.

Locke, J., (1690/1999), An Essay Concerning Human Understanding, The Pennsylvania State University, available online: ftp://ftp.dca.fee.unicamp.br/pub/docs/ia005/humanund.pdf (accessed 20 December 2013)

Luchtenberg, S., (1985), Euphemismen im heutigen Deutsch: Mit einem Beitrag zu Deutschals Fremdsprache, Frankfurt/Main: Lang.

Lutz, W. D., (1989), Doublespeak: from "Revenue Enhancement” to "Terminal Living” How Government, Business, Advertisers, and Others Use Language to Deceive You. Harper \& Row, New York.

Mišić Ilić, B. and M. Radulović, (2014), "Marginalizing Commitment: Syntactic Euphemisms in Political Speeches", Facta Universitatis Niš, Series: Linguistics and Literature. 12 (1): pp. 25-41.

Mišković-Luković, M., (1993), Eufemizmi u savremenom engleskom jeziku, Filološki fakultet u Beogradu, Magistarska teza.

Moritz, I., (2015), Kognitivna analiza eufemizama u političkom diskursu na engleskom jeziku, Doktorski rad, available online: web.ffos.hr/download/ivana-moritz-doktorski-rad.pdf (accessed 10 August 2015)

Partridge, E., (1966), Origins: A Short Etymological Dictionary of Modern English. Routledge, London and New York.

Peacham, H., (1593/1996), The Garden of Eloquence, ed. Beate-Maria Koll. Lang, Frankfurt M./Berlin/Bern/New York.

Penelope, J., (1981), "Language and Communication: Syntactic Euphemism", Papers in Linguistics: International Journal of Human Communication, 14:4: pp. 473-485.

Perelman, C., and L. Olbrechts-Tyteca, (1969), The New Rhetoric: A Treatise on Argumentation, Translated by Wilkinson, J., and Weaver, P., University of Notre Dame Press, Notre Dame.

Puttenham, G., (1589/1968), The Arte of English Poesie: English Linguistics 1500-1800 (A Collection of Fascimile Reprints, No. 110).The Scolar Press Limited, Menston, England.

Quintilianus, M. F., (2001), The Orator's Education, Books 1-10, translated and edited by Russell, D. A., Harvard University Press, Cambridge, Mass.-London.

Radulović, M., (2012), "Expressing Values in Positive and Negative Euphemisms", Facta Universitatis Niš, Series: Linguistics and Literature 10 (1): pp. 19-28.

Radulović, M., (2016), Euphemisms in English and Serbian Public Discourse, Unpublished PhD thesis, University of Niš, Faculty of Philosophy, Niš, Serbia.

Rawson, H., (1981), A Dictionary of Euphemisms and Other Doubletalk. Crown Publishers, Inc., New York.

Reisigl, M., and R. Wodak, (2001), Discourse and Discrimination: Rhetorics of Racism and Antisemitism, Routledge, Taylor \& FrancisGroup,London and New York.

Ristić, S., (2004), Ekspresivna leksika u srpskom jeziku, Institut za srpski jezik SANU, Beograd.

Šebková, K., (2012), Euphemisms, available online: http://is.muni.cz/th/403451/pedf_c/Euphemisms.pdf (accessed 27April 2016)

Schiffrin, D., D. Tannen and H.E. Hamilton, (2001), "Introduction”, In: Schiffrin, D., D. Tannen and H.E. Hamilton (eds.) The Handbook of Discourse Analysis, Blackwell Publishers, Malden Massachusetts/ Oxford: pp. 1-10.

Skinner, Q., (2007),"Paradiastole: Redescribing the Vices as Virtues”, In: Adamson, S., Alexander, G., and Ettenhuber, K., (eds.), Renaissance Figures of Speech,Cambridge University Press,Cambridge: pp. 149-163.

Sperber, D. and D. Wilson, (1981), "Irony and the Use-Mention Distinction”, In: Cole, P. (ed.) Radical Pragmatics, Academic Press, New York: pp. 295-318.

Sperber, D. and D. Wilson, (1995), Relevance: Communication and Cognition. (2nd edition). Blackwell,Oxford.

Strozier, R., (1966),“The Euphemism”, Language Learning 16: pp. 63-70.

Sytnyk, A., (2014), Argumentative Euphemisms, Political Correctness and Relevance. Doctoral thesis, available online: https://doc.rero.ch/record/232366/files/00002415.pdf(accessed 20 June 2015)

Tindale, C. W., (2007), Fallacies and Argument Appraisal, Cambridge University Press, Cambridge.

Van Eemeren, F., B. Garssen and B. Meuffels, (2009), Fallacies and Judgements on Reasonableness: Empirical Research Concerning the Pragma-Dialectical Discussion Rules, Springer, Dordrecht/ Heidelberg/ London/ New York.

Wilson, D., and D. Sperber, (1992),“On Verbal Irony”, Lingua 87: pp. 53-76.

Wilson, D., and D. Sperber, (2012),"Explaining Irony”, Chapter 6 of Meaning and Relevance, Cambridge UP 2012. pp. 123-145, available online $(1-46)$ : http://www.dan.sperber.fr/wp-content/uploads/WilsonSperber_ ExplainingIrony.pdf (accessed 5 December 2014)

Warren, B., (1992), "What Euphemisms Tell Us about the Interpretation of Words”, Studia Lingustica 46: pp. 128-182. 
Newspaper article:

Editorial Board, (31 July 2013), The Evasive Mr. McDonnell, The Washington Post, available online: http://www.washingtonpost.com/opinions/mr-mcdonnell-continues-to-dodge-responsibility/2013/07/31/ 4fff3ef2-f94c-11e2-afc1-c850c6ee5af8_story.html (accessed 7 September 2013)

Political speech:

Miliband, E., (28 September 2010), Leader's Speech, Manchester, available online:

http://www.britishpoliticalspeech.org/speech-archive.htm?speech=212 (accessed 19 September 2012)

\section{EUFEMIZMI KROZ VREME: RETORIČKA MOĆ PALIJACIJE}

U radu se daje pregled ideja i teorijskih okvira relevantnih za analizu eufemizama, reči/izraza koji se koriste kako bi se izbegli negativni efekti koji bi inače bili izazvani alternativnim ne-eufemističnim rečima/izrazima koji imaju negativnije konotacije. Razmatra se mesto eufemizama u retorici, stilistici, pragmatici i analizi diskursa, kao i motivi za upotrebu ovih palijativnih izraza. Pregled ideja i teorijskih okvira pokazuje da se u datim teorijskim okvirima koji pripadaju različitim vremenskim periodima eufemizmi mogu smatrati pogodnim sredstvom za interpretiranje značenja u skladu sa određenim interesima. To znači da se eufemizmi mogu analizirati i kao vrsta jezičke upotrebe koja ima za cilj da nametne poželjnu interpretaciju značenja, a da same motive za upotrebu eufemizama treba sagledati $u$ vezi sa osobenostima konteksta i diskursa u kome se eufemizmi koriste.

Ključne reči: eufemizam, retorika, stilistika, pragmatika, diskurzivne strategije 